\title{
Use of germicides in health care settings-is there a relationship between germicide use and antimicrobial resistance: A concise review
}

\author{
David J. Weber MD, MPH ${ }^{\mathrm{a}, \mathrm{b}, *}$, William A. Rutala PhD, MPH ${ }^{\mathrm{b}}$, Emily E. Sickbert-Bennett PhD, MS ${ }^{\mathrm{a}, \mathrm{b}}$ \\ ${ }^{a}$ Department of Hospital Epidemiology, University of North Carolina Hospitals, Chapel Hill, NC \\ ${ }^{\mathrm{b}}$ Division of Infectious Diseases, University of North Carolina School of Medicine, Chapel Hill, NC
}

Key Words:

Disinfectant

Antibiotic

Chemical sterilants

Antibiotic resistance

\begin{abstract}
A B S T R A C T
Despite the widespread use of disinfectants and antiseptics in hospitals, acquired resistance to current disinfectants has rarely been reported. Germicides, as with medications, should only be used when their benefit as demonstrated by scientific studies exceeds possible risks to human health or the environment.
\end{abstract}

\section{BACKGROUND}

The Centers for Disease Control and Prevention (CDC) stated, "Antibiotics are the foundation of modern medicine," and noted that antibiotics "have transformed health care around the world-making once deadly diseases treatable and saving millions of lives."1 ${ }^{1}$ Not surprisingly, then, antibiotics are frequently administered to hospitalized patients. From 2006 to 2012, 55.1\% of inpatients received at least 1 dose of antibiotics during their hospitalization, and the overall national days of therapy was 755 per 1000 patient days. ${ }^{2}$ A prospective point prevalence study in 2007 of 14,414 patients in 1265 intensive care units from 75 countries reported that, on the day of study, $71 \%$ of all patients were receiving antibiotics. ${ }^{3}$ Although antibiotics can be lifesaving, antibiotic use is associated with an increased risk of Clostridioides difficile and Candida, allergic reactions, drug interactions, adverse events (eg, renal failure), and development of antibiotic resistance. ${ }^{1}$ Importantly, the CDC estimates that 30\% to 50\% of antibiotics prescribed in hospitals are unnecessary or inappropriate. ${ }^{4}$ Further, the CDC has stated that, "There is no doubt that overprescribing and misprescribing are contributing to the growing challenges posed by Clostridioides difficile and antibiotic-resistant bacteria." ${ }^{4}$ The World Health Organization has observed that, "Antibiotic resistance is one of the biggest threats to global health, food security, and development today." each year in the United States at least 2 million people get an antibiotic-resistant infection and at least 23,000 people die as a result. ${ }^{6}$

\footnotetext{
* Address correspondence to David J. Weber, MD, 2153 Bioinformatics Building, CB\# 7030, Chapel Hill, NC, 27599-7030.

E-mail address: dweber@unch.unc.edu (D.J. Weber)

Conflicts of interest: None to report.
}

Antiseptics (eg, alcohol, chlorhexidine, iodine compounds) are widely used in health care for hand hygiene by health care personnel, ${ }^{7,8}$ skin antisepsis for invasive procedures (eg, placement of a central venous catheter), ${ }^{7,8}$ skin antisepsis of patients and surgical staff prior to surgery, ${ }^{9}$ daily bathing of patients residing in an intensive care unit, $^{8}$ and oral care of intubated patients. ${ }^{10}$ Low-level disinfectants (eg, sodium hypochlorite, quaternary ammonium compounds, improved hydrogen peroxide, quaternary ammonium compounds and alcohol) are recommended to be used in the United States for daily and terminal patient room cleaning and disinfection and for cleaning and disinfection of shared patient equipment. ${ }^{11-13}$ High-level disinfectants and chemical sterilants (eg, glutaraldehyde, ortho-phthalaldehyde) are used to perform high-level disinfection on semicritical items (eg, gastrointestinal endoscopes, vaginal specula, laryngoscopes) or chemical sterilization of heat-sensitive critical items. ${ }^{11-13}$

Given the growing threat of antibiotic resistance, the issue of whether there is cross-resistance in bacteria between antibiotics and germicides used in health care has been repeatedly raised in recent decades. The twofold issues are (1) whether antibiotic-resistant bacteria is more likely to exhibit resistance to one or more germicides than a similar but non-antibiotic resistant strain, and (2) whether bacteria that demonstrate increased tolerance or reduced susceptibility to germicides are more likely to exhibit antibiotic resistance. The issues of cross-resistance between antibiotics and germicides have been reviewed. ${ }^{14-25}$

\section{TERMINOLOGY}

The importance of using the proper terminology when discussing the relationship between antibiotic and germicide resistance has 
Table 1

Similarities and differences between antibiotic and germicide resistance

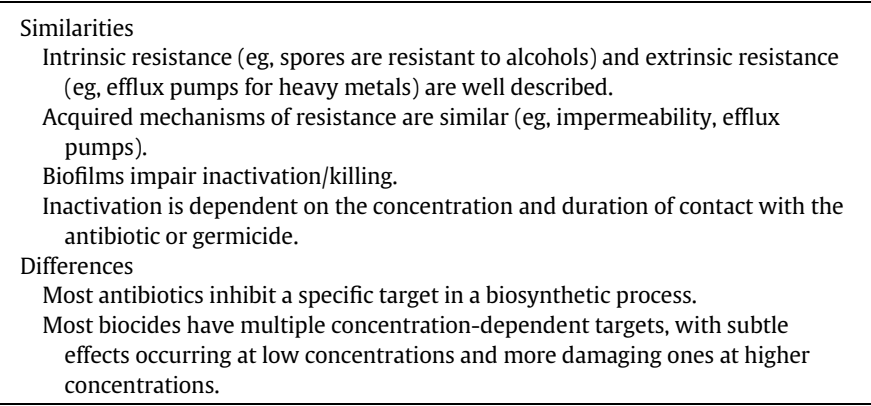

been emphasized in several reviews. ${ }^{16-18,24}$ Biocidal agents (also termed germicides), including antiseptics (germicides used on the skin) and disinfectants (germicides used on surfaces or patient instruments and equipment), inactivate microorganisms. Disinfectants with high-level effectiveness inactivate all microorganisms, with the exception of high numbers of bacterial spores. Low-level disinfectants kill most bacteria and some viruses and fungi, but they cannot be relied on to kill more resistant microorganisms, such as tubercle bacilli or bacterial spores.

The main objective of susceptibility testing of antibiotics is to predict the outcome of treatment with the antibiotics tested. The minimum inhibitory concentration (MIC) is the fundamental measurement that forms the basis for most susceptibility testing methods. The implication of the "susceptible" category implies that an infection due to the strain being tested may be appropriately treated with the dosage of antibiotic agent recommended for the type of infection and infecting species. The breakpoint for determining susceptibility is based principally on pharmacokinetic parameters and results of in vitro studies, animal studies, and human clinical trials. Many factors affect both the validity of the test (eg, composition of the medium, size of the inoculum, duration of incubation, temperature) and the actual clinical efficacy of the therapy (eg, host defenses, site of infection, presence of a foreign body or abscess).
Resistant strains are not inhibited by the usual achievable systemic concentrations of the agent with normal dosage schedules and/ or likely have specific microbial resistance mechanisms (eg, beta-lactamases), and the clinical efficacy of agents to inhibit these strains has not been reliably demonstrated in treatment studies. In contrast to its precise use in reference to antibiotic therapy, the term "resistant" has been used loosely when referring to the activity of a germicide. Authors have described microbes that possess an elevated MIC to a germicide as "resistant" even though the microbe is inactivated by the germicide at its recommended use concentration. Thus, the term "resistant" is incorrect when applied to pathogens exhibiting an elevated MIC to a germicide. The more accurate terms are "reduced susceptibility" or "increased tolerance."

Most cases that are attributed by the user to resistance turn out to be episodes in which the disinfectant was misused, including (1) use of an inappropriate product (ie, the pathogen exhibits intrinsic resistance to the disinfectant); (2) application of the product without regard to proper duration, concentration, $\mathrm{pH}$, or temperature; (3) failure to remove organic debris (ie, improper cleaning) prior to disinfection; (4) insufficient contact of the disinfectant with the surface to be treated; and (5) insufficient availability of the active product (eg, failure to use a proper dilution of an iodophor, because free iodine may be present in lower concentrations in more concentrated products).

\section{MECHANISMS OF BACTERIAL RESISTANCE TO ANTIBIOTICS AND GERMICIDES}

As noted above, antibiotic resistance in several common human pathogens is a worldwide problem. Antimicrobial resistance may be intrinsic (an inherent property of the specific bacterial species) or acquired. Mechanisms of intrinsic resistance include cell impermeability and efflux. ${ }^{16,17}$ Common mechanisms of acquired resistance include the following: target site alteration, altered cell permeability, enzymatic modification or destruction, bypass of sensitive steps, or efflux pumps. ${ }^{14,16,17}$ The mechanisms of germicide resistance are similar to those responsible for antibiotic resistance, but there are some differences (Table 1 ).

Table 2

Selected studies comparing germicide susceptibility in antibiotic resistant and susceptible strains

\begin{tabular}{|c|c|c|c|}
\hline Author (year) & Bacteria studied & Germicides evaluated & Results \\
\hline Al-Masaudi et al $(1988)^{26}$ & Staphylococcus aureus (MSSA, MRSA) & Phenolics, chlorhexidine & $\begin{array}{l}\text { All strains were inactivated at the recommended } \\
\text { germicide concentrations. }\end{array}$ \\
\hline Anderson et al $(1997)^{27}$ & Enterococcus (VSE, VRE) & QAC, phenolic, iodophor & $\begin{array}{l}\text { All strains were inactivated at the recommended } \\
\text { germicide concentrations. }\end{array}$ \\
\hline Rutala et al $(1997)^{28}$ & $\begin{array}{l}\text { S aureus (MSSA, MRSA), S epidermidis, } \\
\text { Enterococcus, Escherichia coli, } \\
\text { Pseudomonas aeruginosa, } \\
\text { Salmonella choleraesuis }\end{array}$ & Phenolic, QAC & $\begin{array}{l}\text { In } 20 \text { comparative trials, only once did the antibi- } \\
\text { otic resistant strain exhibit reduced susceptibility } \\
\text { to a germicide. }\end{array}$ \\
\hline Sakagami and Kajimura $(2002)^{29}$ & Enterococcus (VSE, VRE) & $\begin{array}{l}\text { Alcohol, chlorhexidine, glutaraldehyde, } \\
\text { formalin }\end{array}$ & $\begin{array}{l}\text { All strains were inactivated at the recommended } \\
\text { germicide concentrations. }\end{array}$ \\
\hline Rutala et al $(2006)^{30}$ & $\begin{array}{l}\text { S aureus (MSSA, MRSA), Enterococcus } \\
\text { (VSE, VRE) }\end{array}$ & $\begin{array}{l}\text { Alcohol, chlorine, benzyl ammonium } \\
\text { chloride, phenolic }\end{array}$ & $\begin{array}{l}\text { All strains were inactivated at the recommended } \\
\text { germicide concentrations. }\end{array}$ \\
\hline Wisplinghoff et al (2007) $)^{31}$ & Acinetobacter baumannii & Alcohol, chlorhexidine, iodine, triclosan & $\begin{array}{l}\text { All strains were inactivated at the recommended } \\
\text { germicide concentrations. }\end{array}$ \\
\hline Koo et al $(2012)^{32}$ & Klebsiella (NDM-1) & Alcohol, chlorine dioxide & $\begin{array}{l}\text { Routine disinfection was successful in curtailing } \\
\text { this outbreak. }\end{array}$ \\
\hline Robustillo et al $(2012)^{33}$ & Klebsiella pneumoniae (KPC) & $\begin{array}{l}\text { Alcohol, chlorhexidine, benzalkonium } \\
\text { chloride }\end{array}$ & $\begin{array}{l}\text { Routine disinfection was successful in curtailing } \\
\text { this outbreak. }\end{array}$ \\
\hline Campos et al $(2012)^{34}$ & MRSA & $\begin{array}{l}\text { Sodium hypochlorite, chlorhexidine, } \\
\text { QAC }\end{array}$ & $\begin{array}{l}\text { All strains were inactivated at the recommended } \\
\text { germicide concentrations. }\end{array}$ \\
\hline
\end{tabular}

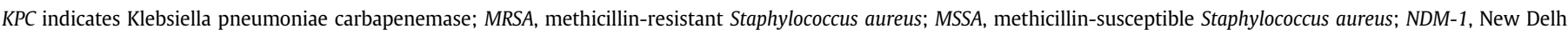
metallo- $\beta$-lactamase; QAC, quaternary ammonium compound; VRE, vancomycin-resistant Enterococcus; VSE, vancomycin-susceptible Enterococcus. 
Table 3

Summary of the relationship between germicide use and antibiotic resistance

\begin{tabular}{ll}
\hline Question & Answer \\
\hline $\begin{array}{l}\text { Does the use of disinfectants or antiseptics result in disinfec- } \\
\text { tant and/or antiseptic resistance to the recommended con- } \\
\text { centrations of the antiseptics or disinfectants? }\end{array}$ & No \\
$\begin{array}{l}\text { Do antibiotic-resistant bacteria exhibit resistance to the rec- } \\
\text { ommended concentrations of antiseptics or disinfectants? }\end{array}$ & No \\
$\begin{array}{l}\text { Does the use of currently recommended hospital disinfectants } \\
\text { and/or antiseptics precipitate antibiotic resistance? }\end{array}$ & No \\
$\begin{array}{l}\text { Does the recommended use of antiseptics and disinfectants in } \\
\text { hospitals decrease the burden of health care-associated } \\
\text { infections? }\end{array}$ & Yes \\
$\begin{array}{l}\text { Conclusion: Regarding the continued use of antiseptics and disinfectants as cur- } \\
\text { rently recommended, the benefits overwhelming exceed the risks. }\end{array}$ \\
\hline
\end{tabular}

\section{LABORATORY-INDUCED REDUCED SUSCEPTIBILITY TO GERMICIDES}

In the laboratory, it has been possible to develop mutants with reduced susceptibility to germicides that demonstrate decreased susceptibility or resistance to antibiotics. Reduced susceptibility was most commonly shown to chlorhexidine, benzalkonium chloride, and triclosan. Importantly, the latter 2 agents are no longer used in health care facilities.

\section{INACTIVATION OF ANTIBIOTIC-RESISTANT BACTERIA BY DISINFECTANTS}

Multiple investigations of laboratory-induced cross-resistance have frequently tested antibiotics that are of limited or no clinical relevance (Table 1). ${ }^{26-34}$ Although some investigators described reduced susceptibility to some germicides, resistance to recommended use concentrations of the germicides was not reported. Disinfectant classes tested included alcohols, aldehydes, iodine compounds, cation surfactant and amphoteric compounds, and biguanide-containing agents. Rarely, clinical or environmental bacterial isolates, some associated with outbreaks, have demonstrated survival at high or in-use concentrations of antiseptics or low-level disinfectants. ${ }^{21}$ To date, widespread dissemination of a bacterial strain resistant to the in-use concentration of commonly used hospital antiseptics or disinfectants has not been reported. In addition, the susceptibility of antibiotic-resistant pathogens to surface disinfectants used at the appropriate dilution has been investigated. When germicides were diluted to their recommended use dilution (or even below), antibiotic-resistant pathogens did not demonstrate reduced susceptibility to germicides (Table 2). Table 3 summarizes the relationship between germicide use and antibiotic resistance.

\section{RELEVANCE OF QAC GENES IN STAPHYLOCOCCI}

Staphylococci are the only bacteria in which the genetic aspects of plasmid-mediated antiseptic- and disinfectant-resistant mechanisms have been described. Decreased susceptibility to chlorhexidine and quaternary ammonium compounds has been reported to be widespread among methicillin-resistant Staphylococcus aureus strains. Tolerance is mediated by the QAC family of genes, which code for proton-dependent export proteins involved in an efflux system that actively reduces intracellular accumulation of toxicants, such as quaternary ammonium compounds. Strains carrying $Q A C$ genes may exhibit reduced susceptibility to aminoglycosides and/or tetracycline. Coagulase-negative staphylococci frequently also contain $Q A C$ genes. Studies have established that the QAC genes consist of 2 gene families, $Q A C C D$ (now referred to as $S M R$ ) and $Q A C A B$.

\section{References}

1. Centers for Disease Control and Prevention. Antibiotic Use in the United States, 2017: Progress and Opportunities. Available from: https://www.cdc.gov/antibiotic-use/stewardship-report/index.html. Accessed March 11, 2019.

2. Baggs J, Fridkin SK, Pollack LA, Srinivasan A, Jernigan JA. Estimating national trends in inpatient antibiotic use among US hospitals from 2006 to 2012. JAMA Intern Med 2016;176:1639-48

3. Vincent JL, Rello J, Marshall J, Silva E, Anzueto A, Martin CD, et al. International study of the prevalence and outcomes of infection in intensive care units. JAMA 2009;302:2323-9.

4. Centers for Disease Control and Prevention. Antibiotic Prescribing and Use in Hospitals and Long-Term Care. Available from: https://www.cdc.gov/antibiotic-use/ healthcare/index.html. Accessed March 11, 2019.

5. World Health Organization. Antibiotic resistance. Available from: https://www. who.int/news-room/fact-sheets/detail/antibiotic-resistance. Accessed March 11, 2019.

6. Centers for Disease Control and Prevention. Antibiotic/Antimicrobial Resistance (AR/AMR). Available from: https://www.cdc.gov/drugresistance/about.html. Accessed March 11, 2019.

7. Ellingson K, Haas JP, Aiello AE, Kusek L, Maragakis LL, Olmsted RN, et al. Strategies to prevent healthcare-associated infections through hand hygiene. Infect Control Hosp Epidemiol 2014;35:937-60.

8. Marschall J, Mermel LA, Fakih M, Hadaway L, Kallen A, O'Grady NP, et al. Strategies to prevent central line-associated bloodstream infections in acute care hospitals: 2014 update. Infect Control Hosp Epidemiol 2014;35(Suppl 2): S89-107

9. Anderson DJ, Podgorny K, Berríos-Torres SI, Bratzler DW, Dellinger EP, Greene L, et al. Strategies to prevent surgical site infections in acute care hospitals: 2014 update. Infect Control Hosp Epidemiol 2014;35:605-27.

10. Klompas M, Branson R, Eichenwald EC, Greene LR, Howell MD, Lee G, et al. Strategies to prevent ventilator-associated pneumonia in acute care hospitals: 2014 update. Infect Control Hosp Epidemiol 2014;35:915-36.

11. Rutala WA, Weber DJ. Guideline for disinfection and sterilization in healthcare facilities, 2008. Available from: https://www.cdc.gov/infectioncontrol/guidelines/ disinfection/index.html. Accessed March 10, 2019.

12. Rutala WA, Weber DJ. Disinfection, sterilization, and antisepsis: An overview. Am J Infect Control 2016;44:e1-6

13. Rutala WA, Weber DJ. Disinfection and sterilization in health care facilities: An overview and current issues. Infect Dis Clin North Am 2016;30:609-37.

14. Poole K. Mechanisms of bacterial biocide and antibiotic resistance. J Appl Microbiol 2002;92(Suppl):55S-64S.

15. Russell AD. Similarities and differences in the responses of microorganisms to biocides. J Antimicrob Chemother 2003;52:750-63.

16. Russell AD. Biocide use and antibiotic resistance: the relevance of laboratory findings to clinical and environmental situations. Lancet Infect Dis 2003;3: 794-803

17. Weber DJ, Rutala WA. Use of germicides in the home and the healthcare setting: is there a relationship between germicide use and antibiotic resistance? Infect Control Hosp Epidemiol 2006;27:1107-19.

18. Cerf O, Carpentier B, Sanders P. Tests for determining in-use concentrations of antibiotics and disinfectants are based on entirely different concepts: "resistance" has different meanings. Int J Food Microbiol 2010;136:247-54.

19. Meyer B, Cookson B. Does microbial resistance or adaptation to biocides create a hazard in infection prevention and control? J Hosp Infect 2010;76: 200-5.

20. Oggioni MR, Furi L, Coelho JR, Maillard JY, Martínez JL. Recent advances in the potential interconnection between antimicrobial resistance to biocides and antibiotics. Expert Rev Anti Infect Ther 2013;11:363-6.

21. Harbarth S, Tuan Soh S, Horner C, Wilcox MH. Is reduced susceptibility to disinfectants and antiseptics a risk in healthcare settings? A point/counterpoint review. J Hosp Infec 2014;87:194-202.

22. Pal C, Bengtsson-Palme J, Kristiansson E, Larsson DG. Co-occurrence of resistance genes to antibiotics, biocides and metals reveals novel insights into their co-selection potential. BMC Genomics 2015;16:964.

23. Kampf G. Acquired resistance to chlorhexidine - is it time to establish an 'antiseptic stewardship' initiative? J Hosp Infect 2016;94:213-27.

24. Maillard JY. Resistance of bacteria to biocides. Microbiol Spectr 2018;6:1-2.

25. Maillard JY. Bacterial resistance to biocides in the healthcare environment: should it be of genuine concern? J Hosp Infect 2007;65(Suppl 2):60-72.

26. Al-Masaudi SB, Day MJ, Russell AD. Sensitivity of methicillin-resistant Staphylococcus aureus strains to some antibiotics, antiseptics and disinfectants. J Appl Bacteriol 1988;65:329-37.

27. Anderson RL, Carr JH, Bond WW, Favero MS. Susceptibility of vancomycin-resistant enterococci to environmental disinfectants. Infect Control Hosp Epidemiol 1997; 18:195-9.

28. Rutala WA, Stiegel MM, Sarubbi FA, Weber DJ. Susceptibility of antibiotic-susceptible and antibiotic-resistant hospital bacteria to disinfectants. Infect Control Hosp Epidemiol 1997;18:417-21.

29. Sakagami Y, Kajimura K. Bactericidal activities of disinfectants against vancomycin-resistant enterococci. J Hosp Infect 2002;50:140-4. 
30. Rutala WA, White MS, Gergen MF, Weber DJ. Bacterial contamination of keyboards: efficacy and functional impact of disinfectants. Infect Control Hosp Epidemiol 2006;27:372-7.

31. Wisplinghoff H, Schmitt R, Wöhrmann A, Stefanik D, Seifert H. Resistance to disinfectants in epidemiologically defined clinical isolates of Acinetobacter baumannii. Hosp Infect 2007;66:174-81.

32. Koo VS, O'Neill P, Elves A. Multidrug-resistant NDM-1 Klebsiella outbreak and infection control in endoscopic urology. BJU Int 2012;110:E922-6.
33. Robustillo Rodela A, Díaz-Agero Pérez C, Sanchez Sagrado T, Ruiz-Garbajosa P, Pita López MJ, Monge V. Emergence and outbreak of carbapenemase-producing KPC-3 Klebsiella pneumoniae in Spain, September 2009 to February 2010: control measures. Euro Surveill 2012;17(7)

34. Campos GB, Souza SG, Lob O TN, Da Silva DC, Sousa DS, Oliveira PS, et al. Isolation, molecular characteristics and disinfection of methicillin-resistant Staphylococcus aureus from ICU units in Brazil. New Microbiol 2012;35: 183-90. 